\title{
Review of the type material of three species of Polietina Schnabl \& Dziedzicki (Diptera, Muscidae) ${ }^{1}$
}

\author{
Silvio Shigueo Nihei ${ }^{2,3}$
}

\begin{abstract}
${ }^{1}$ Contribution number 1408 of the Departamento de Zoologia, Universidade Federal do Paraná.
${ }^{2}$ Programa de Pós-graduação em Entomologia, Departamento de Zoologia, Universidade Federal do Paraná. Caixa Postal 19020, 81531-980 Curitiba, PR, Brazil. E-mail: silvionihei@uol.com.br

${ }^{3}$ Bolsista do CNPq e PDEE-CAPES.
\end{abstract}

\begin{abstract}
Resumo. Revisão do material-tipo de três espécies de Polietina Schnabl \& Dziedzicki (Diptera, Muscidae). O materialtipo de três espécies de Polietina foi examinado. Polietina flavidicincta (Stein, 1904) é redescrita com designação de um lectótipo; P. stellata (Couri, 1982) é considerada sinônimo júnior de P. flavithorax (Stein, 1904) e, para esta, designa-se um lectótipo. O neótipo designado anteriormente é invalidado.

Palavras-Chave. Polietina flavidicincta; P. flavithorax; P. stellata; taxonomia; tipos.

Abstract. The type material of three species of Polietina Schnabl \& Dziedzicki, 1911 was examined. Polietina flavidicincta (Stein, 1904) is redescribed and a lectotype is designated; $P$. stellata (Couri, 1982) is considered junior synonym of $P$. flavithorax (Stein, 1904), and for the latter a lectotype is designated. The neotype previously designated is considered invalid.
\end{abstract}

Keywords. Polietina flavidicincta; P. flavithorax; P. stellata; taxonomy; types.

Polietina Schnabl \& Dziedzicki, 1911 is an essentially Neotropical genus, with its geographical range extending from southern United States of America (Texas) to southern South America (Argentina, Paraguay and Brazil) (CARVALHO \& CoURI 2002). The genus was revised by Couri \& CARVALHO (1997) and, at that time, it comprised 13 species. Subsequently, other five species have been added to the genus: CouRI \& CARVALHO (1996) describing two species, and Couri \& PAMPLona (1997) transferring three species from Cyrtoneurina Giglio-Tos, 1893. In this paper, the type material of three species of the genus is revised and discussed.

Polietina flavidicincta (Stein, 1904) was referred by CARvalho et al. (1993) and Couri \& CARVAlHo (1997) as having its type material destroyed. In fact, the male syntype deposited at Magyar Nemzeti Museum (Budapest) was destroyed in 1956 (A. C. Pont, pers. com.), however, STEIN (1904) had also deposited two female syntypes at the Museum für Naturkunde (Berlin). According to A. C. Pont (pers. com.), one of these syntypes still remains deposited at the Berlin Museum. This syntype was examined and is designated herein as lectotype and, based on it and on additional material, a redescription of the species is presented.

Similarly, the type material of P. flavithorax (Stein, 1904) had been deposited at the Budapest and Berlin museums. The syntypes deposited at the Budapest Museum was considered destroyed by CARVAlHo et al. (1993) and, hence, a neotype was designated by Couri \& CARVALHO (1997). When describing the species, STEIN (1904) stated that six syntypes ( 3 males and 3 females from Peru, Callanga) were deposited at the Budapest Museum and, apart from that material, two females (from Brazil) described as morphologically different were deposited at the
Berlin Museum. The material in Budapest was destroyed in 1956, however, A. C. Pont (pers. com.) had found two syntypes (male and female) and the two Brazilian specimens in Berlin. When describing species using reasonably numerous type series, Stein used to keep some specimens in his own collection, which now is mostly at the Museum für Naturkunde, Berlin (Pont 2001). The finding of those syntypes makes the neotype designation by Couri \& CARVALHo (1997) invalid (A. C. Pont, pers. com.). Those syntypes were examined and a lectotype is designated herein. Nevertheless, the invalid neotype is conspecific to the syntypes and for this reason a redescription is not required, as the species was redescribed thoroughly by Couri \& CarvalHo (1997).

The purpose of the lectotype designations is to fix the identity of the names to the respective name-bearing specimens designated for P. flavidicincta and P. flavithorax, and to clarify any taxonomic doubt involving those names. Based on this statement, the lectotype designations herein can be considered valid under the ruling of the International Code of Zoological Nomenclature (InTERNATIONAL COMISSION ON ZOOLOGICAL NOMENCLATURE 1999).

At last, Cyrtoneurina stellata Couri, 1982 was transferred to Polietina by Couri \& PAMPLona (1997), concomitantly with the genus revision of COURI \& CARVALHo (1997). Recently, it was possible to examine the holotype deposited at the Museu Nacional, Universidade Federal do Rio de Janeiro (Rio de Janeiro), what showed that $P$. stellata should be regarded as junior synonym of $P$. flavithorax (Stein, 1904).

The material examined belongs to the following institutions: The Natural History Museum, London, United Kingdom (BMNH); Colección Boliviana de Fauna, La Paz, 
Bolivia (CBFC); Coleção de Entomologia "Pe. J. S. Moure", Departamento de Zoologia, Universidade Federal do Paraná, Curitiba, Brazil (DZUP); Museu Nacional, Universidade Federal do Rio de Janeiro, Rio de Janeiro, Brazil (MNRJ); Museu de Zoologia, Universidade de São Paulo, São Paulo, Brazil (MZSP); Museo de Historia Natural "Noel Kempff Mercado", Santa Cruz de la Sierra, Bolivia (UASC); Museum für Naturkunde, Humboldt-Universität, Berlin, Germany (ZMHU).

\section{Polietina flavidicincta (Stein, 1904)}

(Figs. 1-5)

Aricia flavidicincta Stein, 1904: 420 (male/female description, key), lectotype female (ZMHU) designated herein, type-locality: "Cordill. v. Columbien, terra templada" [Colombia].

Phaonia flavidicincta; Stein, 1911: 68 (Bolivia); 1918: 208 (Venezuela); 1919: 112 (catalogue).

Lasiomala flavidincta [sic]; Enderlein, 1927: 52 (list).

Poecilophaonia flavidincta [sic]; Séguy, 1937: 339 (catalogue).

Polietina flavidicincta; Albuquerque, 1956: 19 (catalogue); Pont, 1972: 55 (catalogue); Carvalho et al., 1993: 63 (catalogue); Couri \& Carvalho, 1997: 256 (comments); Carvalho \& Couri, 2002: 55 (list).

Distribution. Venezuela, Colombia, Bolivia.

Redescription. Female. Antennae dark brown, lighter at the apex of pedicellum and base of arista. Parafacial gray and silver pollinose, frontal vitta blackish. Proboscis brown; palpi brown, the apical half slightly lighter. Scutum dark brown with silver pollinosity and paired faint stripes dorsally; humeral callus dark brown. Scutellum dark brown with silver pollinosity. Calypters yellowish. Wings hyaline with a brown macula extending from the apex of $\mathrm{Sc}$ to apex of $\mathrm{R}_{2+3}$, and brown spots at the $\mathrm{r}-\mathrm{m}$ and $\mathrm{dm}-\mathrm{cu}$ crossveins. Legs dark brown. Abdomen dark brown with silver pollinosity, tergite 2 with translucid lateral areas, very close at the median line, and tergite 3 with yellow lateral areas at its anterior margin.

Head: eyes ciliated short and sparsely. 8-9 pairs of frontal setae, 1 strong proclinate and 2 reclinate pairs; interfrontal setae present. Parafacial bare. Genae with a set of short setae upwardly directed and situated above subvibrissal setae. Arista plumose, and with developed secondary cilia on the inner-dorsal face Palpi slightly spatulated at apex.

Thorax: acrostichal setae 2:1; dorsocentral setae 2:4; 3 humeral setae, the innermost reduced; 1 posthumeral seta and a strong cilia anteriorly; 3 notopleural setae, the median slightly shorter than the posterior one; strong presutural seta; 2 intraalar setae; 2 supra-alar setae, the anterior very strong, about twice the second one; 2 postsupra-alar setae, the posterior very strong, about twice the anterior one; prealar seta strong, slightly longer than the anterior notopleural seta. Scutellum with a short pair of basal setae; 2 lateral pairs, the anterior one strong; a preapical and a strong apical pairs; lateral portion of scutellum setulose below the scutellar setae. Anepisternum with a row of 5 strong backward setae at posterior margin, and with a developed upward seta in the upper anterior corner. Katepisternal setae 1:2. Anepimeron with inferior and superior portions ciliated; greater ampulla bare; anatergite bare; katatergite pubescent; posterior spiracle ciliated on posterior margin; metakatepisternum ciliated above hind coxa; meron ciliated below spiracle. Postalar wall with the median tuft of setulae; suprasquamal ridge ciliated on anterior region.

Wing: apical portion of stem-vein bare on dorsal and ventral faces. $R_{1}$ ciliated dorsally but bare at the $1 / 8$ basal portion; $\mathrm{R}_{4+5}$ ciliated, with dorsal cilia almost reaching apex and ventrally, ciliated on basal half of the length until r-m crossvein; node of Rs densely ciliated on both faces. M ciliated ventrally between $\mathrm{r}-\mathrm{m}$ and $\mathrm{dm}$-cu crossveins. Subcostal sclerite with 2 ventral cilia.

Legs: fore femur with a complete row of setae on dorsal, posterodorsal and posteroventral faces. Fore tibia with a submedian seta on posteroventral face; the anterodorsal face without median seta; a preapical seta on dorsal, posterodorsal and posteroventral faces. Fore tarsi with developed cilia; tarsomeres $1>2>3>4<5$. Mid femur with a sparse row of setae on posteroventral face, shorter at apical half; 2 short preapical setae on anterodorsal face; and 3 preapical seta obliquely aligned on dorsal to posterodorsal face. Mid tibia with 4 sparse setae in all extension of the posterior face; a submedian and an apical seta on posteroventral face; and a strong apical seta on ventral and anteroventral faces. Mid tarsi with reduced sensitive cilia; tarsomeres as in fore tarsi. Hind coxa bare on posterior face. Hind femur with a complete row of setae on anterodorsal face; a complete row of sparse setae on anteroventral face; a row of setae on posteroventral face, longer setae at basal half; a preapical seta on dorsal and anterodorsal faces, and 2 preapical oblique setae on posterodorsal to posterior face. Hind tibia with a series of setae on all extension of the anterodorsal face, with the 2 longest setae at the submedian and 2/3 limits; 2 setae at the apical half of anteroventral face; a long seta (calcar) at apical third and a shorter one at basal forth of the posterodorsal face; and a preapical seta on anterodorsal, dorsal and anteroventral faces. Hind tarsi with reduced sensitive cilia; tarsomeres as in fore tarsi.

Abdomen: sternite 1 ciliated. Terminalia (Figs. 4-5): tergites 6 and 7 enlarged at base. Sternites 6 and 7 thin and slightly enlarged at base and with a separate plate posteriorly. Membranous area between segments 7 and 8 with a pair of ventral tuberculus, flat-rounded-shape membranous structures with a very weak sclerotization; that structure is present in all species of the genus. Tergite 8 with the sclerotised plates diverging posteriorly and with the region around the marginal setae somewhat sclerotised. Sternite 8 with two pairs of short and strong spines, the outer pair stronger than the inner one.

Male. Differs from the female by the following: head holoptic, with about 11 pairs of frontal setae, no proclinate and one reclinate pair; no interfrontal setae. Terminalia: sternite 5 as in Fig. 1; cercal plate (Fig. 2) with the median and marginal spined processes, with some microtrichiae adjacent to the median process, and the marginal process with three and two developed spines on each side of the plate and some small spines located more marginally; edeagus (Fig. 3) with weakly 

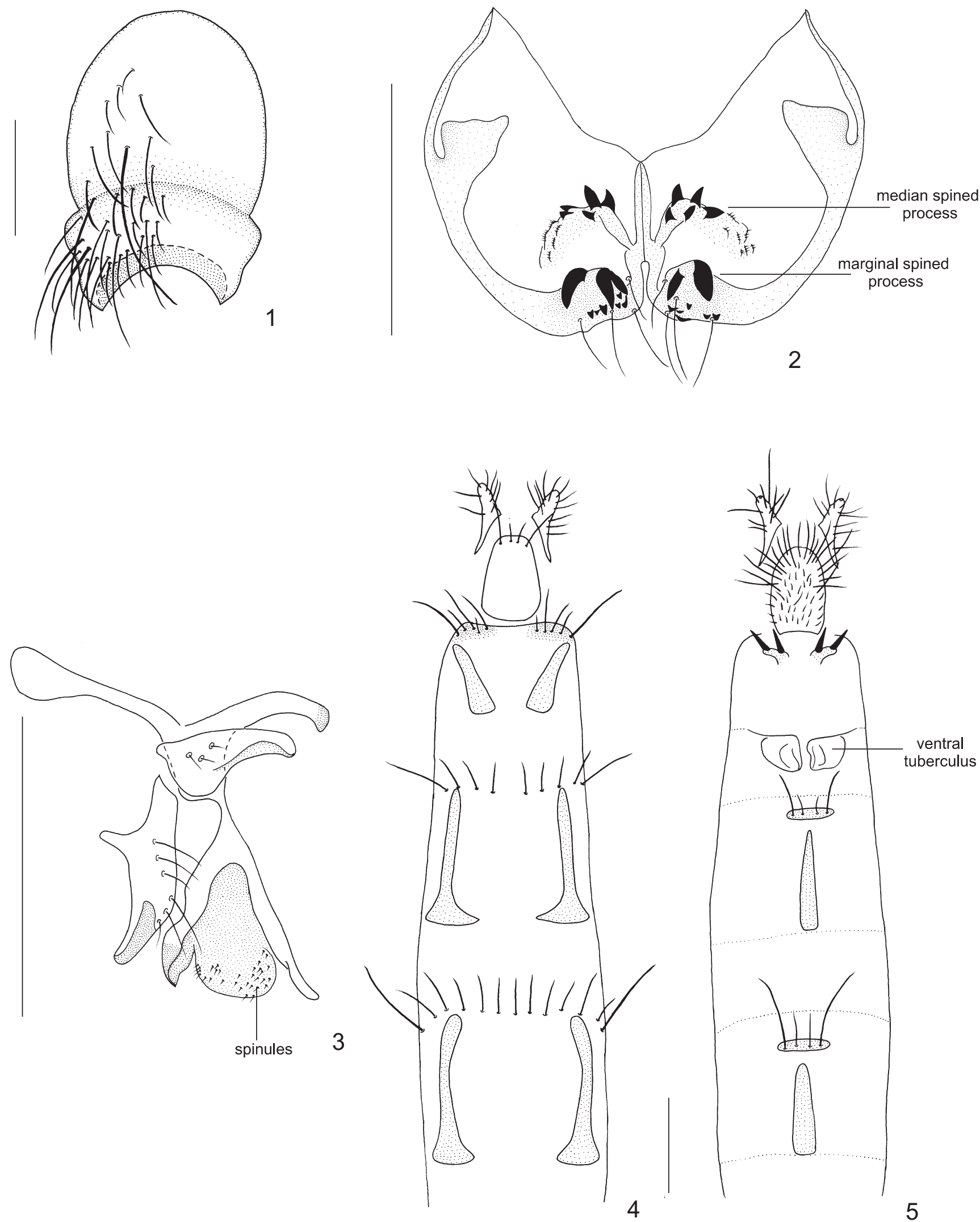

Figs. 1-5. Polietina flavidicincta (Stein): 1, male sternite 5; 2, male cercal plate, ventral view; 3, male edeagus; 4, female terminalia, dorsal view; $\mathbf{5}$, female terminalia, ventral view. (Scale bars=0.2 $\mathrm{mm}$ ) 
sclerotised spinules at the membranous portion of distiphallus.

Measurements. Lectotype: body length $7 \mathrm{~mm}$, wing length $6.8 \mathrm{~mm}$; paralectotypes: body length 7-7.9 $\mathrm{mm}(\mathrm{n}=3)$, wing length 6.6-7.4 $\mathrm{mm}(\mathrm{n}=3)$.

Type material. Lectotype female, by present designation, deposited at ZMHU and labelled as follows: "Cordill. v. Collumbien/ terra templada/ Thieme S." [light green label]; "13859" [on underside of label]; "Type" [light red label]; "Zool. Mus./ Berlin"; with an added label "LECTOTYPE \% / Polietina flavidicincta/ (Stein, 1904)/ des. S.S. Nihei 2004". The second female syntype mentioned by STEIN (1904) is missing.

Stein's additional material at ZMHU: there are also one female from Bolivia, Mapiri, Lorenzopata, 2000 m, 9.V.1903, and one male (with the abdomen dissected and described herein) from the same locality but collected on 11.V.1903. Although clearly labelled as types by Stein, these two specimens do not belong to the syntypes' series examined by STEIN (1904); the male is part of the material studied by STEIN (1911). Together with this material, there is also one female (with the abdomen dissected and described herein) from Colombia (no additional collecting data), labelled by Stein. All the three specimens are conspecific to the lectotype. The dissected specimens had their abdomens conditioned in a micro-vial with glycerine pinned together with the respective specimen.

\section{Polietina flavithorax (Stein, 1904)}

Aricia flavithorax Stein, 1904: 416 (male/female description, key), lectotype male (ZMHU) designated herein, type-locality: Peru, Callanga.

Phaonia flavithorax; Stein, 1911: 62, 67 (male/female diagnosis, key, Peru, Bolivia); 1918: 208 (male redescription, comments, Venezuela, Brazil, Bolivia); 1919: 112, 168 (catalogue).

Poecilophaonia flavithorax; Malloch, 1921: 171 (genotype designation); 1928: 313 (citation); Séguy, 1937: 339 (list).

Lasiomala flavithorax; Enderlein, 1927: 52 (genotype designation).

Polietina flavithorax; Hennig, 1965: 70 (comments); Pont, 1972: 55 (catalogue); Carvalho et al., 1993: 63 (catalogue); Couri \& Carvalho, 1997: 257-258, 265, figs. 14-20 (neotype designation, male/female redescription, key, comments); Carvalho \& Couri, 2002: 53 (key).

Cyrtoneurina stellata Couri, 1982: 51, figs. 26-29 (male description), holotype male (MNRJ), type-locality: Brazil, Rio de Janeiro, Represa Rio Grande; Carvalho et al., 1993: 55 (catalogue). Syn. nov.

Polietina stellata; Couri \& Pamplona, 1997: 414, figs. 6-12 (male redescription, comments); Carvalho \& Couri, 2002: 52-53 (key, comments).

Distribution. Venezuela, Brazil (Mato Grosso, Rio de Janeiro, Paraná), Peru, Bolivia, Paraguay.

Morphological variation. Some significant variations were noted which should be reported here. On the ventral surface of the cercal plate, the number of spines of the median spined process, in some specimens with less spines than others (see Fig. 10 from Couri \& PAMPLona 1997 and Fig. 16 from Couri \& CARVALHO 1997). The number of spines varyes among the individuals, and even in the same individual the number of spines can be different on each side of the cercal plate.

With regard to colouration, variation mainly in the thorax and legs was observed. Apart from the humeral callus (always yellowish), the thorax varyes dorsally from yellow to brown mainly in the middle, and laterally from yellow to brownish yellow. The forelegs are always yellow; the midlegs entirely yellow, or yellow with the apex of the femur darker, or entirely brownish; the hindlegs varying as the midlegs. This variation has no correlation with the geographic distribution of the studied specimens, with some variation occurring in specimens from a same locality. Such a similar variation was observed in P. orbitalis (pers. obs.).

Type material of P. flavithorax. Lectotype male, by present designation, deposited at ZMHU and labelled as follows: "Peru/ Callanga."; "Type" [light red label]; "Phaonia/ flavithorax/ Type Stein

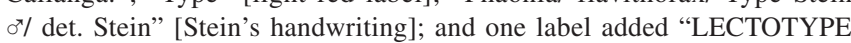
$0^{7 /}$ Polietina flavithorax/ (Stein, 1904)/ des. S.S. Nihei 2003". Specimen in good condition. Paralectotype: 1 female (ZMHU) labelled as the lectotype, but an added label: "PARALECTOTYPE o / Polietina flavithorax/ (Stein, 1904)/ des. S.S. Nihei 2003". Specimen in good condition. Both specimens placed with an lateral label at its right side "SYNTYPE $10^{*} 1$ 의 Aricia/ flavithorax Stein/ Conf. A.C. Pont 1999".

Stein's additional material at ZMHU: 1 female labelled "Brasil. Beyrich"; "5150"; "Mus./ Berol."; "Aricia/ flavithorax/ \& Stein" [Stein's handwriting]; and 1 female labelled "Brasilien/ Beyrich"; "Mus./ Berol.". These two specimens were referred to by STEIN (1904) but only to comment about some morphological variation observed. Also, 1 male labelled "Peru-Urubambafl./ 11.IX.03/ Umahuankilia"; "flavithorax/ Type $\sigma^{x}$ Stein" [Stein's handwriting]; and 1 female labelled "PeruMeshagua/ 28.IX.03/ Urubamba"; "Phaonia/ flavithorax/ Type + / det. Stein" [Stein's handwriting]. Although clearly labelled as types, these two specimens do not belong to the syntypes' series examined by STEIN (1904), they consist in the very same material studied and listed in STEIN (1911).

Type material of $P$. stellata. Holotype male of $P$. stellata deposited at the MNRJ and labelled as follows: "Repr. Rio Grande/ Rio de Janeiro/ Brasil"; "F.M.Oliveira/ vii.72"; "Holótipo"; "Polietina stellata/ (Couri, 1982)/ Pamplona \& Couri det."; "Cyrtoneurina stellata/ Couri/ M.S.Couri det." [Couri's handwriting]. Specimen in reasonable conditions, with the left wing broken and the left fore and midlegs lacking; the abdomen dissected and conditioned in a micro-vial with glycerine pinned separately from the specimen.

Additional material. BRAZIL. Mato Grosso: Cáceres, C. Elias leg., 21.XI.1984 (1 male, 1 female, DZUP), 01.XII.1984 (1 female, DZUP), 17.XII.1984 (1 male, 2 females, DZUP), 24.XII.1984 (2 females, DZUP, 1 female, MNRJ), 20.I.1985 (1 male, DZUP), 30.I.1985 (3 females, DZUP), 18.V.1985 (1 female, MNRJ). Rio de Janeiro: Parque Nacional do Itatiaia (850m), 27/29.XI.1970, J.H. Guimarães leg. (4 males, MZSP); Itatiaia, 700m, II.1959, W. Zican leg. (1 male, MZSP). Paraná: Curitiba, 04.XI.1999, J.A.P. Silva leg. (1 female, DZUP); Morretes, 17.V.1985, C.I.I.F. leg. (1 male, DZUP); São José dos Pinhais, 19.X.1984, C.I.I.F leg. (1 female, DZUP), 01.XII.1986, Lev. Ent. Profaupar leg. (1 female, DZUP). PERU. Previsto, 700m, J. Schunke leg., 04.V.1964, (1 male, BMNH), 10.VI.1965 (1 male, BMNH), 850m, 06.VI.1965 (1 male, BMNH), 700m, 12.VI.1965 (1 female, BMNH). BOLIVIA. Santa Cruz: Las Trancas, 16.IV.1998, F. Coro leg. (1 female, UASC); Beni: Yacuma, 24.VII.1993, H. W. Rogg leg. (1 female, CBFC). Cochabamba: Ayopaya (Rio Cotacajes), 25.VIII.1992, C. Pruett leg. (1 female, CBFC). PARAGUAY. Canindeyú: Reserva Natural Bosque Mbaracayú, A.C.F. Costa leg., 29.III/09.IV.1996 (1 male, DZUP), 10/ 16.IV.1996 (1 female, DZUP), 24/28.V.1996 (1 female, DZUP), 12/ 19.VI.1996 (1 male, DZUP).

Acknowledgements. Thanks to the following curators for the loan of material: David Notton (BMNH), Eliana M. Cancello (MZSP), Jaime Sarmiento (CBFC), Joachim Ziegler (ZMHU), Márcia S. Couri (MNRJ) and María Julieta Ledezma (UASC). Special thanks to David Notton $(\mathrm{BMNH})$ and Joachim Ziegler (ZMHU) for the facilities and assistance provided during my visits. Thanks are also due to Claudio J. B. de Carvalho, Maureen Turcatel and Antônio J. C. Aguiar (DZUP) for comments and suggestions on the manuscript, and to Jaime I. RodríguezF. (DZUP) who personally brought on loan the specimens from the 
Bolivian collections and made possible their examination. I am also indebted with Adrian Pont (Oxford University Museum of Natural History) for providing me information on the location of some type specimens and making me available his manuscript on Stein's type material. Financial support received from the Conselho Nacional de Desenvolvimento Científico e Tecnológico-CNPq (Proc. $\mathrm{n}^{\circ}$. 141936/ 2000-2) and from Coordenação de Aperfeiçoamento de Pessoal de Nível Superior-CAPES (Proc. $n^{\circ}$. 0321/03-6).

\section{REFERENCES}

Albuquerque, D. O. 1956. Fauna do Distrito Federal. XIII. Sôbre o gênero Polietina Schnabl \& Dziedzicki, 1911, com descrições de espécies novas (Diptera, Muscidae). Boletim do Museu Nacional do Rio de Janeiro (Zoologia) 139: 1-31.

Carvalho, C. J. B. DE \& M. S. Couri. 2002. Part I. Basal groups, p.17132. In: C. J. B. De Carvalho (ed.). Muscidae (Diptera) of the Neotropical Region: taxonomy. Curitiba, Editora Universidade Federal do Paraná.

Carvalho, C. J. B. de; M. S. Couri; A. C. Pont; D. M. Pamplona \& S. M. Lopes. 1993. Part II. Muscidae. In: C. J. B. De Carvalho (ed.). A Catalogue of the Fanniidae and Muscidae (Diptera) of the Neotropical Region. São Paulo, Sociedade Brasileira de Entomologia, $201 \mathrm{p}$.

Couri, M. S. 1982. Adenda ao trabalho de Snyder (1954) sobre Cyrtoneurina Giglio-Tos, 1893 (Diptera, Muscidae, Cyrtoneurininae). Revista Brasileira de Entomologia 26: 37 53.

Couri, M. S. \& C. J. B. De Carvalho. 1996. Duas novas espécies de Polietina Schnabl \& Dziedzicki (Diptera, Muscidae) do Brasil. Revista Brasileira de Zoologia 12: 825-831 [1995].

Couri, M. S. \& C. J. B. De Carvalho. 1997. Revision of Polietina Schnabl \& Dziedzicki (Diptera, Muscidae) and considerations on its new systematic position. Revista Brasileira de Zoologia 14: 255281.

Couri, M. S. \& D. M. Pamplona. 1997. Sobre a identidade de quatro espécies descritas em Cyrtoneurina Giglio-Tos com diagnoses e redescrição (Diptera, Muscidae). Revista Brasileira de Biologia 57: 411-415.
Enderlein, G. 1927. Dipterologische studien. XVIII. Konowia 6: 5056.

Ferrar, P. 1987. A guide to the breeding habits and immature stages of Diptera Cyclorrhapha. Part 1. Leiden, E.J. Brill/ Scandinavian Science Press, Entomonograph 8, 478 p.

Hennig, W. 1965. Vorarbeiten zu einem phylogenetischen System der Muscidae (Diptera: Cyclorrhapha). Stuttgarter Beiträge zur Naturkunde 141: 100 p.

InTERNATIONAL COMISSION ON ZOOLOGICAL NOMENCLATURE. 1999. International Code of Zoological Nomenclature. London, The International Trust for Zoological Nomenclature, $306 \mathrm{p}$.

Malloch, J. R. 1921. Exotic Muscaridae (Diptera). I. Annals and Magazine of Natural History 7: 161-173.

Malloch, J. R. 1928. Exotic Muscaridae (Diptera). XXII. Annals and Magazine of Natural History 2: 307-319.

Meier, R.; M. Kotrba \& P. Ferrar. 1999. Ovoviviparity and viviparity in the Diptera. Biological Reviews 74: 199-258.

Pont, A. C. 1972. 97. Family Muscidae, 111 p. In: A Catalogue of the Diptera of the Americas South of the United States. São Paulo, Museu de Zoologia, Universidade de São Paulo.

Pont, A. C. 2001. The type-material of Diptera in the Staatliches Museum für Tierkunde Dresden (Insecta). Part IV: Fanniidae and Muscidae. Entomologische Abhandlungen 59: 455-492.

Séguy, E. 1937. Diptera, Family Muscidae, 604 p. In: P. Wytsman (ed.). Genera Insectorum. Fasc. 205. Brussels.

Skidmore, P. 1985. The biology of the Muscidae of the world. Dordrecht, W. Junk Publishers, Series Entomologica, vol. 29, xiv +550 p.

Stein, P. 1904. Die Amerikanishen anthomyiden des Köiglishen Museums für Naturkunde zu Berlin und des Ungarishen National-Museum zu Budapest. Annales Historico-Naturales Musei Nationalis Hungarici 2: 414-495.

Stein, P. 1911. Die von Schnuse in Südamerika gefangenem Anthomyiden. Archiv für Naturgeschichte 77: 61-189.

Stein, P. 1918. Zur weitern Kenntnis aussereuropäischer Anthomyiden. Annales Historico-Naturales Musei Nationalis Hungarici 16: $147-244$.

Stein, P. 1919. Die Anthomyidengattungen der Welt, analytisch bearbeitet, nebst einem kritisch-systematischen Verzeichnis aller aussereuropaischen Arten. Archiv für Naturgeschichte 83 (A1): 85-178.

Received 11.III.2003; accepted 30.I.2004 